\title{
Claudia Bouteligier, Dialoog in recht en literatuur. Kritiek van de narratieve rede
}

\author{
Irawan Sewandono
}

Claudia Bouteligier, Dialoog in recht en literatuur. Kritiek van de narratieve rede (OudTurnhout/'s-Hertogenbosch: Gompel \& Scavina), 2018, ISBN 978-94-6371-062-6, $295 p$.

Bouteligier vindt het recht maar een kille abstractie en rechtspraak een louter mechanische bedoening. Zij zoekt steun bij de narratieve ethiek die vanuit de filosofie de ethische werking van het literaire verhaal onderzoekt (p. 26). Deze methode past Bouteligier toe op het recht. Zij beperkt zich daarbij tot de cognitieve variant van empathie: het inleven in de situatie van de ander. De emotionele variant, het emotionele invoelen, laat zij buiten beschouwing (p. 40-41). Het menselijke dreigt te worden weggeredeneerd als de rechter geen empathie toont jegens de ander over wie hij moet oordelen, als hij verkiest om op mechanische wijze te beslissen als ware hij slechts de spreekbuis van de wet (p. 47). De auteur vraagt zich af of de narratieve rechtsethiek met haar notie van empathie een oplossing kan bieden om de mechanische benadering van het recht te doorbreken (p. 51). Het woord kritiek in de ondertitel van het boek moet worden opgevat in de zin van Kant. Zij maakt verder een afweging tussen voordelen en beperkingen van de vooronderstellingen in de narratieve rechtsethiek (p. 59).

Bouteligier heeft zich verdiept in de literaire werken van Dostojevski, Buber, Sartre en Camus. De Russisch-orthodoxe Dostojevski is teleurgesteld in de idealen van de Verlichting en de Franse Revolutie. Hij heeft niet veel op met het roomskatholicisme en het socialisme (p. 256). De echte christelijke naastenliefde wordt vergeten als wetenschap en kennis worden verabsoluteerd. Hij laat de lezer ervaren dat onrecht wordt gedaan wanneer we de ander uit het oog verliezen (p. 112-113). De Oostenrijks-Israëlische theoloog Buber schrijft dat we de ander bevooroordeeld benaderen als we volstaan met alleen maar definities en categorieën. De dialoog is onmisbaar om in de ontmoeting te treden (p. 153). Het gaat erom dat men zich verantwoordelijk weet voor de naaste. Het ethische ontspringt aan de ontmoeting van mens tot mens; het gaat er niet aan vooraf (p. 154). Bouteligier wijst hier op de sprong die de rechter volgens Paul Scholten altijd, ook als hij met een syllogistische redenering kan volstaan, moet nemen in zijn beslissing. De rechterlijke beslissing is een handeling die uiteindelijk wortelt in het geweten van degene die deze verricht. Deze beslissing is nooit herleidbaar tot waarnemen en logisch betoog. Het is een wilsverklaring: zo moet het. Het is tenslotte een sprong, gelijk iedere daad, ieder zedelijk oordeel dat is (aldus: Algemeen deel, Asser serie, Zwolle: W.E.J. Tjeenk Willink, 1974 (1931), p. 130). Als ik Bouteligier goed heb begrepen, ziet zij deze sprong als onverplicht. Met de sprong kan de rechter de kloof tussen de abstracte regel en het concrete geval overbruggen. Door wel of 
niet te springen kiest hij tussen het mechanisch hanteren van een syllogisme of het treden in de dialoog (Bouteligier p. 144).

Het Franse existentialisme gaat niet uit van het geloof in God, maar van de mens. Sartre bouwt voort op Dostojevski (p. 196). We kunnen de ander niet werkelijk leren kennen uit zijn verhalen. Deze staan in de weg aan de dialoog en verijdelen de ontmoeting met de ander (p. 200). Dit is ook van betekenis voor de rechtsvinding. Het recht kan niet anders dan de mens laten samenvallen met het beeld dat uit zijn eigen verhaal blijkt en hem onderbrengen in abstracte categorieën. Volgens Bouteligier mag de rechter echter niet volstaan met het veroordelen van een mens op basis van diens eigen narratieve identiteit. Een mens is altijd in wording en valt niet samen met dat zelf opgeroepen beeld (eveneens p. 200). In De Vreemdeling van Camus (Amsterdam: De Bezige Bij, 1961) blijft de verdachte alsmaar zwijgen en wordt hij uiteindelijk bij verstek veroordeeld. Hij is en blijft niet onder een noemer te vangen. Hij is niet meer dan een gestileerde narratieve constructie. Iedere vorm van dialoog over zijn schuld of onschuld ontbreekt (p. 239-240). In mijn woorden: de ontmoeting moet van twee kanten komen; niet alleen de rechter, maar ook de verdachte moet stappen zetten.

Uit haar eerste vijf hoofdstukken trekt Bouteligier twee voorlopige conclusies. De humanistische conceptie van liefde is volgens haar gericht op de mensheid als geheel en dan wordt de concrete naaste gepasseerd. Hieruit moet de conclusie worden getrokken dat empathie als inlevingsvermogen en narratieve rechtsethiek geen remedie kunnen bieden tegen het abstracte mechanisme van het recht. Ten eerste kan abstractie niet worden opgeheven door de notie van empathie als inlevingsvermogen omdat empathie eveneens op basis van veralgemeniseringen functioneert (p. 263-264). Ten tweede is ook de narratieve constructie van de ander gebaseerd op logica, causaliteit en noodzaak. Het verhaal kan de beweging en de mogelijkheid van de mens niet omvatten en biedt daarom geen alternatief voor de mechanische rechtsvinding (p. 265).

Maar als dit de teleurstellende voorlopige uitkomst van haar onderzoek is, wat dan? In het zesde hoofdstuk, 'De legende van de Grootinquisiteur', ontleedt Bouteligier tot op het bod het verhaal in het verhaal van De gebroeders Karamazow van F.M. Dostojevski (Wageningen: L.J. Veen, 1973). De Grootinquisiteur praat daar met de gedetineerde zoon van God over christelijke dogmatiek. De slotconclusie van de auteur is dat de dialoog en de wederzijdse ontmoeting moeten worden verwerkelijkt in de rechtsvinding. De rechter heeft jegens de ander een persoonlijke verantwoordelijkheid. Om een mechanische beslissing te voorkomen, kan hij zich niet verlaten op zijn empathie en inlevingsvermogen. Hij kan en moet, met nadruk op moet, zelf de sprong wagen en een beslissing nemen die ook rechtvaardig is (p. 267).

Uit deze letterkundige werken doemt het beeld op dat rechtsvinding erg mechanisch zou zijn. Dat beeld herken ik helemaal niet. Nu begrijp ik wel dat theorievorming over rechtsvinding iets anders is dan rechtsvinding in de praktijk. Maar ik wil hier toch iets kwijt over de kunst van het gedrieën zitten, praten en schrij- 
ven. Daarbij zij vooraf opgemerkt dat ik de strafrechtelijke actualiteit niet bijhoud. Ik weet echter nog wel dat in het strafproces in Nederland niet de daad maar de dader centraal staat. Wat daarvan zij, ik verdiep me af en toe in bezwaarzaken over bestuursrechtelijke sancties en vanaf de zijlijn heb ik in diverse hoedanigheden vaak meegekeken met rechtspraak. Ik kan dus meepraten over rechtsvinding in het algemeen. Een rechtssysteem is een samenhangend stelsel van regels en beginselen, met nadruk op hun samenhang (law-as-integrity, zie Ronald Dworkin, Law's Empire, Londen: Fontana Press, 1986). Een zaak, hoe moeilijk ook, laat zich oplossen in drie stappen: 1) zet de feiten op een rij: wat voeren partijen aan, waarover zijn zij het eens; 2) selecteer de doorslaggevende regel (c.q. beginsel) en pas deze toe, en 3) vraag je af of de uitkomst redelijk en billijk is (het sprongetje van Scholten). Mocht de uitkomst onbevredigend zijn, dan begin je weer van voren af aan. Dit stappenplan is betrekkelijk soft; de stappen hoeven niet per se in die volgorde te worden gezet.

Het gaat me er vooral om dat het positieve Nederlandse recht wel degelijk ruimte laat voor meer ethiek bij de beraadslaging in de raadkamer en zelfs in de overwegingen van de uitspraak. Aan veel procedurele regels liggen dialoog en ontmoeting ten grondslag; in het bestuursprocesrecht bijvoorbeeld de wettelijke cautieplicht bij bestraffende sancties en de verplichting tot hoor en wederhoor. Ook kan worden gewezen op de genuanceerde bewijslastverdeling bij herstel- en strafsancties en weerlegbare rechtsvermoedens. De keuze tussen gegrond en ongegrond is niet altijd zo zwart-wit. Bij bestraffende sancties in het sociaal domein wordt rekening wordt gehouden met verwijtbaarheid en draagkracht. Iets dergelijks geldt voor het tonen van berouw; er zijn inkeerregelingen. Als de wet aan het bestuursorgaan beslissingsruimte laat, verschaffen zorgvuldigheids- en evenredigheidseisen aanknopingspunten voor inhoudelijke dialoog en ontmoeting. Het vertrouwensbeginsel biedt bij uitstek gelegenheid voor dialoog en ontmoeting; de aanvrager heeft dan met het bestuursorgaan gepraat, dat orgaan heeft iets toegezegd en kan daaraan worden gehouden (ECLI:NL:RVS:2019:1694 en ECLI:NL:CRVB:2019:4351). In het fiscale recht en de sociale zekerheid moet de wet zelfs onder omstandigheden wijken voor vertrouwen en gelijkheid. Er is gewoon veel te veel om op te noemen! Als ethische vragen ter zitting (of elders) aan de orde zijn gekomen, blijft echter in de uitspraak zelf doorgaans een expliciete reactie achterwege. Wij koesteren namelijk hier te lande - in tegenstelling tot de VS en Engeland - het geheim van de raadkamer: de drie rechters overwegen en oordelen collegiaal in alle unanimiteit en doen niet aan die rare separate opinions. Bij het sprongetje van stap 3 van het stappenplan voor rechtsvinding komt het zelden expliciet tot een beslissende eindstemming. Ik heb de voorzitter van de meervoudige kamer eens horen afsluiten met: 'Two noes and one aye, the noes have it'. Daarmee gaf hij een eigen twist aan de befaamde woordspeling van een Amerikaanse president.

Het palet van de rechtsfilosofie is rijk aan kleuren, daarover zijn we het allemaal wel eens. Ik kan ook beamen dat de dialoog en de daadwerkelijk wederzijdse ontmoeting ernstig in gedrang dreigen te komen als in de rechtspraak altijd zou 
worden volstaan met louter mechanische en abstracte toepassing van rechtsregels. Daarvoor is empathie als inlevingsvermogen inderdaad geen remedie. Hetzelfde geldt voor het slechts narratief verstaan van wat de verdachte vertelt. Ik ben onder de indruk van de knappe uitleg die Bouteligier, met haar op het interdisciplinaire vakgebied Recht en Literatuur gebaseerde en zelf verder ontwikkelde methodologie, heeft gegeven aan al die goed gekozen literaire werken. Voor het bestuursrecht is in ieder geval haar grote verdienste dat zij met haar bespiegelingen over dialoog en ontmoeting een mooie filosofische onderbouwing heeft weten te geven aan de informele aanpak in de bezwaarfase en de nieuwe zaaksbehandeling in de bestuursrechtspraak (A.C. Mein en A.T. Marseille, 'Responsieve bezwaarbehandeling in theorie en praktijk', NTB 2019/36 resp. onder meer A. Verburg, Bestuursrechtspraak in balans, Den Haag: Boom juridisch, 2019). 